\title{
Will the Removal of Regulation $Q$ Raise Mortgage Interest Rates?
}

\author{
R. ALTON GILBERT
}

$\mathbf{L}$ the gradual phase-out of interest rate ceilings on deposits by 1986. Some critics of this change have claimed that banks and thrift institutions will charge their borrowers higher interest rates once these deposit interest rate ceilings are removed. According to these eritics, lenders will raise their lending rates to cover their increased deposit costs. ${ }^{1}$

This article presents a brief history of deposit interest rate ceilings in the United States and their effects. It then describes the process established by recent legistation for eliminating ceilings, and its likely impact on the interest rates that borrowers will pay. Finally, the analysis is extended to cover the effects of the All Savers Certificate program on interest rates that depository institutions will charge on loans.

\section{WHY HAS THE FEDERAL GOVERN- MENT REGULATED DEPOSIT INTEREST RATES?}

Federal bank regulators received the legal authority to regulate interest rates that commercial banks may pay depositors in the Banking Acts of 1933 and 1935. The interest ceilings have been set under

\footnotetext{
The view that the elmination of celling interest rates on de powit: would cause interest rates pad by bonowers to rise appears in Depository Listitutions Dorgulation Art of 1979, Heangons. 1347 before the Subcommittee on Financial lnstitutions, Senate Committee on Banking, Housing, and Urban Affars, Part II and Pat III, 96 Cong. I Sess. (Govemment Printing Office, 1979 ). See comments by Ralph W. Pritchard, first vice president, Nittiona Association of Realtors $\langle$ Jure 27,1979 ); Thomas $F$. Bolger, first vice president, Independent Bankers Association (July I8, 1979 : and lenry B. Schechter, director, Deputrment of Urban Affairs, AF LCIO (Tuly 18, 1979 )
}

Regulation $\mathrm{Q}$ of the Federal Reserve and, therefore, are commonly referred to as Regulation $Q$. One of the primary reasons for imposing ceilings on deposit interest rates was to reduce the number of failing banks by reducing their interest cost. Another objective was to reduce the incentives for rural banks to hold large interest-earning balances with their correspondents in the financial centers. ${ }^{2}$

Much of the concem in the early 1930 s centered on interest payments on demand deposits. Interest payments on demand deposits were prohibited under the Banking Acts of 1933 and 1935. The maximum interest rate on all time and savings deposits was initially set at 3 percent, slightly below the average interest rate that commercial banks and thrift institutions had been paying on time and savings deposits, but tbove then-existing market yields on high-grade short-tem securities. ${ }^{3}$ The choice of the initial ceiling rate on time and savings deposits indicates that the purpose of these ceiling rates on time and savings deposits was not to keep them below yields on alternative investments, but to reduce deposit rates slightly and thus lower the interest costs of depository institutions.

During the 20 years from the mid-1930s to the mid-1950s, the ceiling rates on time and savings deposits were above maket interest rates. In 1957 and 1962 , when market interest rates rose near or above the ceiling rates on savings deposits, these ceilings were raised (chart 1 ).

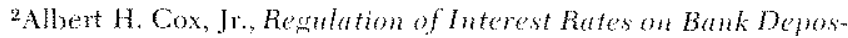
ats, Michigan Business Studies, vol. XVI, no. 4 (Burean of Busi ness Research, University of Mirhigan, 1966 .

sCharlotte E. Ruebling, "The Administmation of Regulation Q" this Recicte (February 1970), pla $30-31$.
} 


\section{Chart 1}

3-Month Treasury Bill Rate and Ceiling Rate on Savings Deposits at Commercial Banks

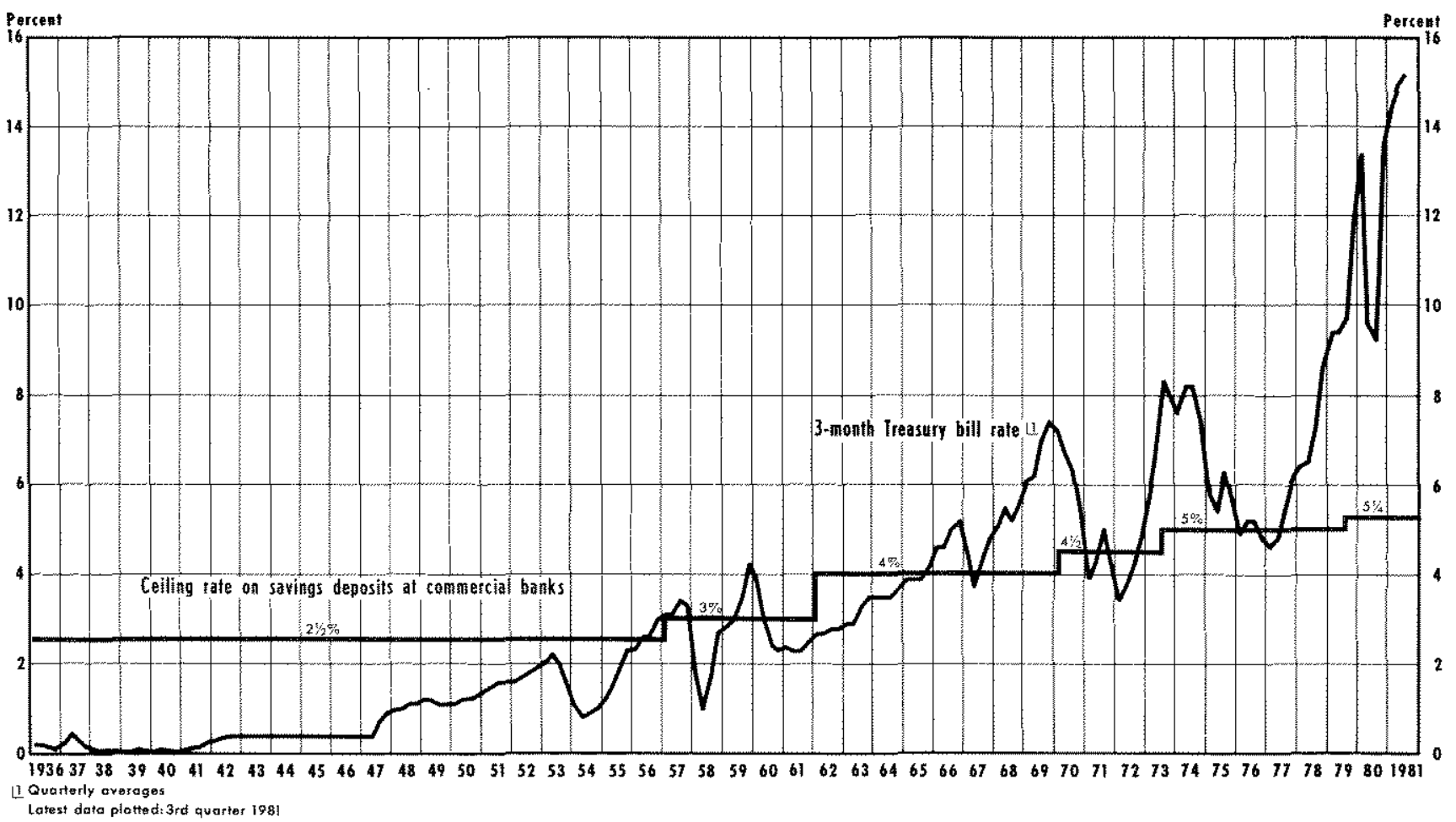

In 1966, interest rate eeilings were imposed on deposits of thrift institutions. Sponsors of the enacting legislation asserted that interest rates were being driven up by competition for deposits among banks and thrifts, and that celling interest rates on deposits at thrift institutions would stop this escalation. They assumed that by permitting slightly higher ceiling rates at thrift institutions specializing in residential mortgage lending, there would be an adequate supply of credit for residential mortgages at reasonable mortgage interest rates. ${ }^{4}$

These controls on interest rates paid by thrift institutions were viewed initially as temporary measures to deal with "unnsual circumstances." Over" time, however, thrift institutions have come to view the differentials between the ceiling interest rates on their deposits and those imposed on commercial banks as essential in attracting deposits to be used

${ }^{4}$ Temporary Interest Rate Controls, Report No. 1777, House Committee on Banking and Cunency, 89 Cong. 2 Sess. (GPO, 1966), and Interest Rates and Mortage Credit, Hearing on $S$. 3687 , 5. 3627 and 5.3529 betore the Senate Committe on Banking and Cutrency, 89 Cong. 2 Sess. (GPO, 1966). for residential montgage lending. These differentials have been considered important elements of a public policy designed to expand the supply of mortgage credit and increase residential construction. ${ }^{5}$

If the differentials in ceiling rates between thrifts and commercial banks are to stimulate the flow of deposits to thrift institutions, celling interest rates on some categories of deposits at commercial banks must be below market interest rates. If all deposit interest rate ceilings were alote market interest rates, the higher ceiling rates at thrift institutions would not induce individuals to hold their deposits there rather than at commercial banks. This would occur because both commercial banks and thrifts would be paying the lower market interest rate to depositors instead of the higher ceiling rates. Since 1966 , the ceiling rate on savings deposits at commercial banks has been below the three-month Treasury bill rate (a measure of market rates) except for only a few months in 1967, 1971, 1972 and 1976 77 (chart 1).

"Preston Martin, "A Case for Regulation Q, Jomnal of the Federal Home Loan Bank Board (October 1970), pis. 1-6. 


\section{THE EFFECTS OF DEPOSIT INTEREST RATE CEILINGS}

If maintaining deposit interest rate ceilings below market interest rates, with slightly higher rates allowed for thrift institutions, was intended to produce a stable supply of mortgage credit available to homebuyers at moderate interest rates, it has failed to do so. The growth of deposits at thrift institutions has slowed whenever market interest rates have risen above the deposit ceiling rates. ${ }^{6}$ These fuctuations in the growth of deposits at thrift institutions may have contributed to the abrupt changes in the pace of residential construction activity in recent decades. $^{7}$

Deposit interest rate ceilings have discriminated against the relatively less wealthy savers. ${ }^{8}$ There are no celling rates on deposits in denominations of $\$ 100,000$ or more. The ceiling rate on money market certificates (time deposits with maturities of six months) fluctuates with market interest rates, but those require a minimum deposit of $\$ 10,000$. Debt obligations of the U.S. Treasury, investments with risk characteristics most similar to deposits of fed erally insured institutions, are sold in minimum denominations that are substantially larger than the average time or savings deposits of individuals.

6Edward F. Mckelvey, Interest Rate Ceilings and Disintermediation. Stafl Economic Studies 99 (Board of Covemors of the Federal Reserve System, 1978).

TDwight M. Jaffee and Kenmeth. T. Rosen, "Mortgage Credit Avilability and Residential Construction," Brookings Papers on Economic Actitity (2: 1979), pp. 333-76; and Neil G. Berkman, "Mortgage Finance and the Housing Cycle," New England Economic Reciew (September/October 1979), pp. 5476. Results of some stadies, however, flo not support the view that changes in the avalability of nortgage credit through thrift institutions infunce residential constuction. See Franciseo Arcelns and Allan H. Meltzert" "The Markets for Housing and Housing Services," Journal of Money, Credit and Banking (February 1973), pp. 78-99; Allan H. Meltzer, "Credit Avalability and Econonic Decisions: Some Evidence from the Mortyage and Housing Markets," Jommal of Finance (Jnme 1974), pp.763-78; and Paul De Rosa, "Mortgage Rationing and Residential Investment: Some Results from a Brainard-Tobin Model, Journal of Money. Credit and Banking (February 1978), pp. 75-87.

sedward 1. Kane, "Shot Changing the Small Saver: Federal Covemment Discrimination atgainst Small Savers during the Vietnan War," fournal of Monem Credit and Banking (Novenber 1970), pp. 513-22, Edward J. Kame, "Consequences of Contemporary Ceilings on Mortgage and Deposit Interest Pates for Households in Different Economic Circumstances," in George M. von In ursenberg, ed. The Gocermment and Capital Fonnation (Ballinger Publishing Company, 1980), pp, 401-11: Charles Clotfelter and Charles Liebernan, "On the Distriburtional Impact of Federal Interest Rite Restrictions," Journat of Finance (March 1978), pp. 199-213, Edward C. Lawence and Gregory E. Elliehanen, "The Impact of Federal Interest Rate Regulations on the Snall Saver: Further Evidence," Joumal of Finaree (June 1981), mp. 677-84.
Consequently, savers with less than $\$ 10,000$, who want an investment with risk and liquidity characteristics similar to Treasury bills, are limited to savings deposits at federally insured institutions. Because of the interest rate ceilings on these deposits, the yield is generally less than that available on Treasury bills. Several studies have estimated that savers have "lost" several billion dollars in earnings as a result of the Regulation $Q$ ceilings. ${ }^{9}$

\section{ELMINATNG REGULATIONQ}

One of the most significant sections of the Depository Institutions Deregulation Act of 1980 calls for the elimination of ceilings on deposit interest rates over a six-year period. The statement of findings and purpose of that section of the act reads as follows:

The Congress hereby finds that -

(1) limitations on the interest rates which are payable on deposits and acconnts discourage persons from saving money, create inequities for depositors, impede the ability of depository institutions to compete for funds, and have not achieved their purpose of providing an even flow of funds for home mortgige lending; and

(2) all depositors, and particnlarly those with nodest savings, are entitled to receive a market rate of retmm on their savings as soon as it is economically feasible for depository instifutions to pay such rate. ${ }^{10}$

The act does not specify a timetable for eliminating deposit interest rate ceilings, but delegates those decisions to a newly created committee: the Depository Institutions Deregulation Committee (DIDC). Voting members of the DIDC include: Secretary of the Treasury; and chairmen of the Federal Reserve Board, Federal Deposit Insurance Corporation, Federal Home Loan Bank Board, and National Credit Union Administration. The Comptroller of the Currency is a non-voting member of the DIDC.

"Butce W. Morgan, "Ceilings on Depesit Interest Rates, the Saving Public and Housing Finance," Eamity for the Small Sacer Hearings on S.Con. Res 5 before the Subcommittee on Financial Institutions, Senate Committee on Banking, Housing, and Urban Altairs, 96 Cong 1 Sess. (GPO, 1979), 1) 175; David H. Pyle, "The Losses on Savings Deposits from Interest Rate Regwhation," Bell Joumal of Economic and Management Sctunce Autum 1974) pp. 614-22; David H. Pyle, "Interest Rate Ceilings and Net Worth Losses by Savers," in Kenneth $\mathrm{E}$. Boulding and Thomas Fredesick Wilson, eds., Redistribution thromgh the Finandal System (Praeger Publshers, 1978), pp. 87-101; Robert A. Thuggart, Jt., "Effects of Deposit Rate Ceilings: The Evidence from Massachusetts Savings Banks," Jommal of Money, Credil and Banking (May 1978), pp. 139-57.

10pepositony Listitufions Deregulation and Monetayl Control Acto of 1980, S. kept. No. 96-640,96 Cong. 2 Sess. (CPO, 1980), title II, sec: 202(a). 
The act directs the DIDC to provide for the orderly phase-out and altimate elimination of maximum interest rates that may be paid on time and savings deposits as rapidly ats economic conditions warrant. A primary consideration in determining when conditions warrant raising or eliminating these ceilings is the effect of such changes on the safety and soundness of depository institutions. The act lists the following methods the DIDC maty use in phasing out ceiling interest rates on deposits:

The phase-out of such limitations may be acheved by the Deregelation Committee by the gradual increase in such limitations applable to all existing categones of accounts, the complete elimination of the limitations applicalble to particular categories of accounts, the creation of new categories of accounts not subject to finitations or with limitations set at current maket rates, any combination of the above methods, or any other method. ${ }^{1 \mathrm{I}}$

One limitation imposed on the DIDC is that it may not raise interest rate ceilings on all deposit categories above market interest rates before March 1986.

The DIDC has taken limited actions to raise or eliminate ceilings on deposit interest rates (see taljle 1). The first significant action was to lift caps on ceiling rates for time deposits with maturities of $2 \frac{1}{2}$ years, which was effective August 1, 1981. The DIDC has also created a new category of IRA/Keogh account (with minimum maturity of $1 \frac{1 / 2}{\text { years) that }}$ will have no regulated interest rate ceiling as of January $1,1982$.

\section{THE EFFECTS OP ELMINATING REGULATION O ON INTEREST RATES PAL BN BORROWERS}

The effects of eliminating ceiling rates on deposits cannot be determined by examining the effects of actions already taken by the DIDC, since few actions to eliminate the ceiling rates have been taken so far. Effects of eliminating deposit ceiling rates on the interest rates paid by borrowers must, therefore, be analyzed by considering the effects of eliminating Regulation $Q$ in the context of a theory that describes how interest rates are determined.

\section{The Mark-up Theory es. the Competitive Market Theory}

There are several competing theories of how depository institutions determine the interest rates they charge borrowers. The two theories discussed

1)bid, title 11, sec. $204(a)$. in this section have different implications for the impact of eliminating the ceiling rates on time and savings deposits specified under Regulation $Q$.

The Mark-up Theory - Those who assert that borrowers will be charged higher interest rates due to the elimination of Regulation $Q$ are generaly using a mark-up theory: Depository institutions are presumed to determine the interest rates they charge borrowers ats a mark-up over the average interest rate they pay on deposits. The average interest rate on deposits will rise as Regulation $Q$ is phased out, inless market interest rates should fortuitously fall below the Regulation $Q$ ceilings currently in effect. The mark-up theory, therefore, predicts that borrowers will pay hightr interest rates as a consequence of the elimination of Regulation $Q$.

The Competitive Market Theory - Under this theory, the interaction of several factors influencing both supply and demand determine a market interest rate, which all lenders charge on loans with similar characteristics. Lenders can make lew loans at interest rates above the market rate, since borrowers will search for the lowest rate available. Since lenders can make all the loans they wish at the market rate, they have no incentive to lend at interest rates below the market rate.

To describe this theory in more detail, consider the determinants of the market interest rate on a particular category of credit - residential mortgage loans. Demand for residential mortgage credit is detemined by personal income and the preferences of individuals for housing and for home ownership. Several factors influence the supply of residential mortgage credit. One factor is the interest rates on investments other than residential mortgages. If, for instince, yields rise on U.S. Treasury securities with maturities similar to those of residential mortgages, depository institutions and other suppliers of residential mortage credit will supply less mortgage credit at each level of the mortgage interest rate.

Another important determinant of supply is the interest rate on deposits not subject to Regulation $Q$ ceilings. For example, depository institutions may pay whatever interest rate they wish on time deposits in denominations of $\$ 100,000$ or more. In the competitive market, depository institutions will bid up the interest rates they are willing to pay on deposits free of Regulation Q ceilings until these mates are sufficiently close to their lending rates to eliminate the incentives to make additional loans. Consequently, it is the interest rate that depository 


\section{Table 1}

\section{DIDC Changes in Interest Rate Ceilings on Deposits}

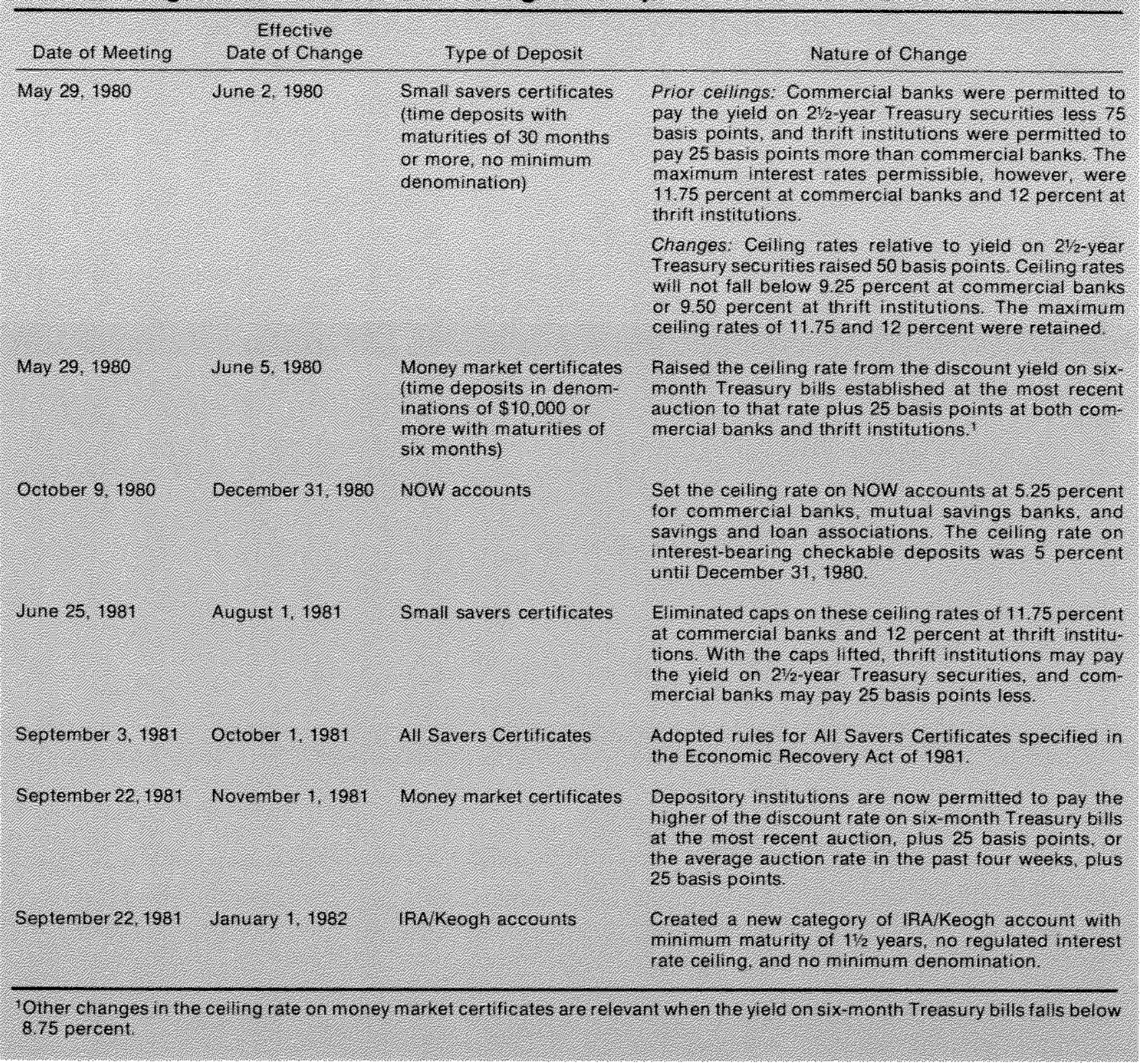

institutions pay on deposits unconstrained by Regulation $Q$ that influences the interest rates they charge on loans.

Under the competitive market theory, a change in Regulation $Q$ ceilings will affect interest rates on residential mortgages only if it affects interest rates on mregulated deposits or on alternative investments. One implication of this theory is that eliminating Regulation $Q$ ceilings might reduce interest rates for borrowers, if individuals are induced to save more of their income in response to the higher interest rates available on deposits.

The effects of eliminating Regulation $Q$ under the competitive market theory are in sharp contrast to the effects under the mark-up theory. The mark-up theory predicts that the elimination of Regulation $Q$ would cause interest rates paid by borrowers to rise, while the competitive market theory suggests that 
Comparison of Mortgage Interest Rate with Cost of Funds
to S\&Ls and 10 -Year Treasury Bond Yield 1

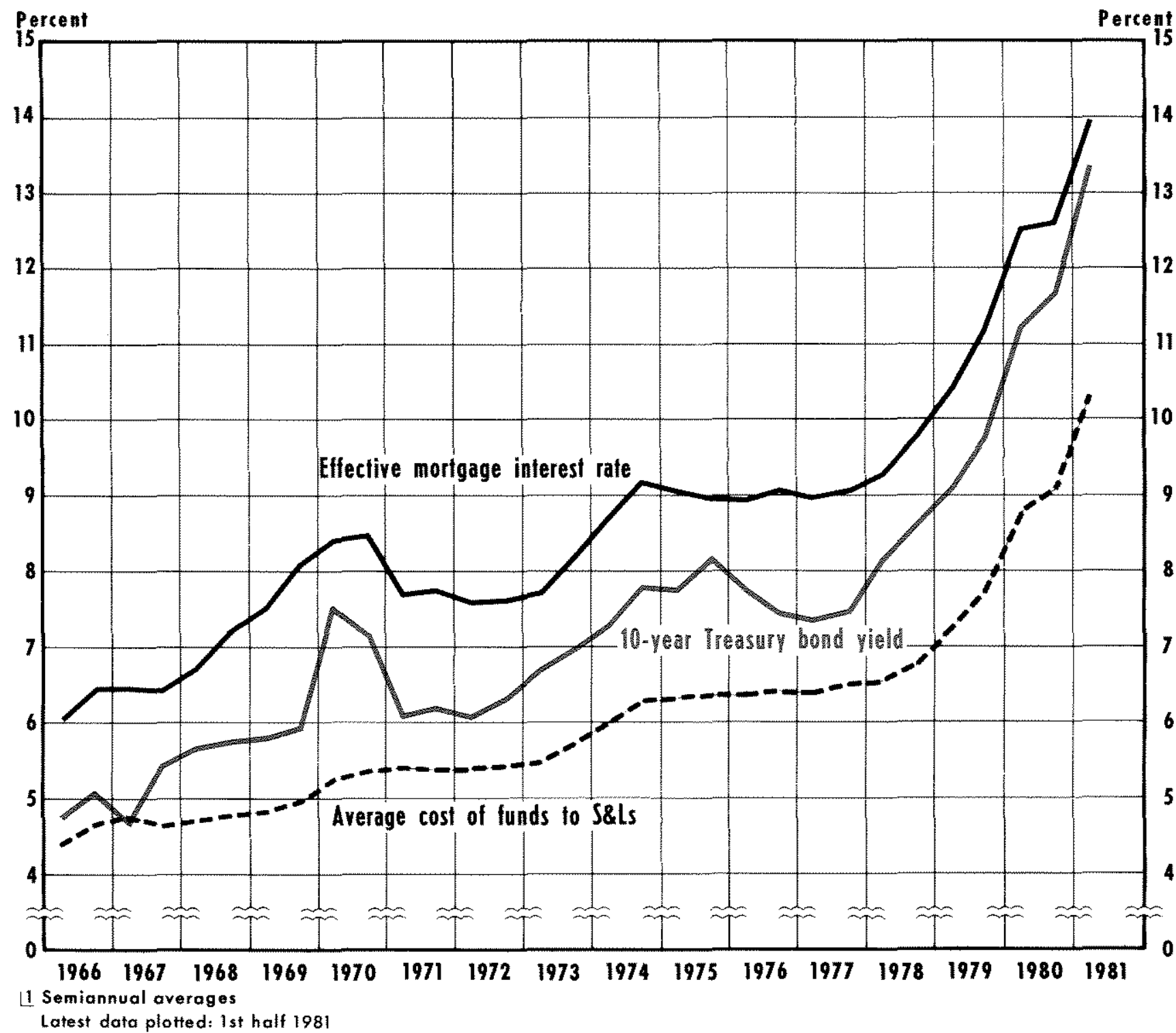

interest rates on loans would either be unaffected or would decline.

What's the Evidence? - Chart 2 presents some evidence on whether U.S. interest rates on residential mortgages are determined according to the mark up or competitive market theory. The average cost of funds to savings and loan associations (S\&Ls) over six-month intervals since 1966 is shown in conjunction with the average interest rate on conventional residential mortgages and the average yield on U.S. Treasury securities with maturities of 10 years over the same six-month periods.

Chart 2 clearly indicates that there is no fixed mark-up between the average cost of funds to $S \& L S$ 
and the average interest rate on residential mortgages. The difference between the average mortgage interest rate and the average cost of funds to S\&Ls has varied widely, from 165 basis points in the first half of 1966 to 386 basis points in the first half of 1980.

Chart 2 shows that there is at much closer relationship between the average mortgage interest rate and the average yield on U.S. Treasury securities with maturities of 10 years than the relationship between the mortgage interest rate and the average cost of funds. ${ }^{12}$ The difference between the mortgage interest rate and the yield on 10-year Treasury bonds has a standard deviation of 27 basis points, compared with a standard deviation of 59 basis points for the difference between the mortgage interest rate and the average cost of funds to S\&Ls.

These comparisons provide evidence that interest rates on residential mortgages are determined in a competitive credit market. Homebuyers must pay interest rates on mortgages that are competitive with yields on alternative investments in order to receive credit.

Chart 3 presents additional evidence on whether interest rates are determined according to the markup or the competitive market theory. The difference between the prime loan rate charged by commercial banks and the average interest rate they pay their depositors on total time and savings deposits is highly variable, ranging from 49 basis points in 1972 to 461 basis points in 1980 . Thus, once again, there appears to be no fixed mark-up between the prime rate and the average interest rate paid on time and savings deposits.

There is a much closer relationship, however, between the prime loan rate and the rate that commercial banks pay on their three-month certificates of deposit, which are free of Regulation Q ceilings. The differential between the prime rate and the three-month certificate of deposit yield has a standard deviation of 73 basis points, compared with a standard deviation of 144 basis points for the differential between the prime rate and the average interest rate paid on time and savings deposits. Again, the interest rate relationships presented in

\footnotetext{
12The condusion that mortgage interest rates are more closely related to the yield on U.S. Treasury securities with maturities of 10 years than to the averige cost of furds to S\&L L has been confimed using regression andysis. See Thomas Mayer and Harold Nathan, "Mortgatge Rites and Regulation Q," Working Paper Series No. 171 (Department of Economics, University of California at Davis, ful 1981).
}

chart 3 are more consistent with the competitive market theory than with the mark-up theory.

\section{Is the Mortgage Market Separate From Other Credit Markets?}

Despite the above evidence suggesting that interest rates charged borrowers are more closely related to market interest rates uncontrolled by Regulation $Q$ than to the average interest rates paid on deposits, the possibility that the elimination of Regulation Q would increase the interest rates paid by one class of borrowers - homebuyers - has not been ruled out. This possibility, produced by certain regulations and tax incentives affecting thrift institutions, is discussed in this section.

Since 1966, the existence of higher ceilings on their deposit interest rates have given thrift institutions an advantage over commercial banks in attracting deposits. At the same time, however, thrift institutions are faced with regulations that limit their investments in types of assets other than mortgages. In addition to these regulations, thrift institutions are also given tax incentives to specialize in residential mortgage lending: The deductions from gross income allocated to bad debt reserves, which are, therefore, not subject to income tax, are larger for institutions that invest more of their assets in mortgages.

As a result of the higher ceiling interest rates allowable (which attract deposits) and the regulations and tax incentives that favor mortgage lending, thrift institutions might charge residential mortgage lending rates that are below market interest rates (on securities with characteristics similar to residential mortgages). Eliminating Regulation $Q$ would remove the advantage that thrift institutions have in attracting deposits. As a result, the share of credit channeled to residential mortgages would decline and interest rates on residential mortgages would rise relative to other interest rates.

This result is unlikely for several reasons. First, the reactions by other suppliers of credit would tend to offset these effects, as long as non-thrift institutions are making residential mortgage loans as well. If thrift institutions increase the amount of mortgage credit they offer at prevailing interest rates, other lenders will simply reduce the quantity of residential mortgage credit they supply, shifting their investments to other sectors of the credit market. The net result might be no change in mortgage interest ates, but an increase in the proportion of 
Chart 3

\section{Relationship Between the Commercial Bank Prime Rate and Selected Deposit Interest Rates}

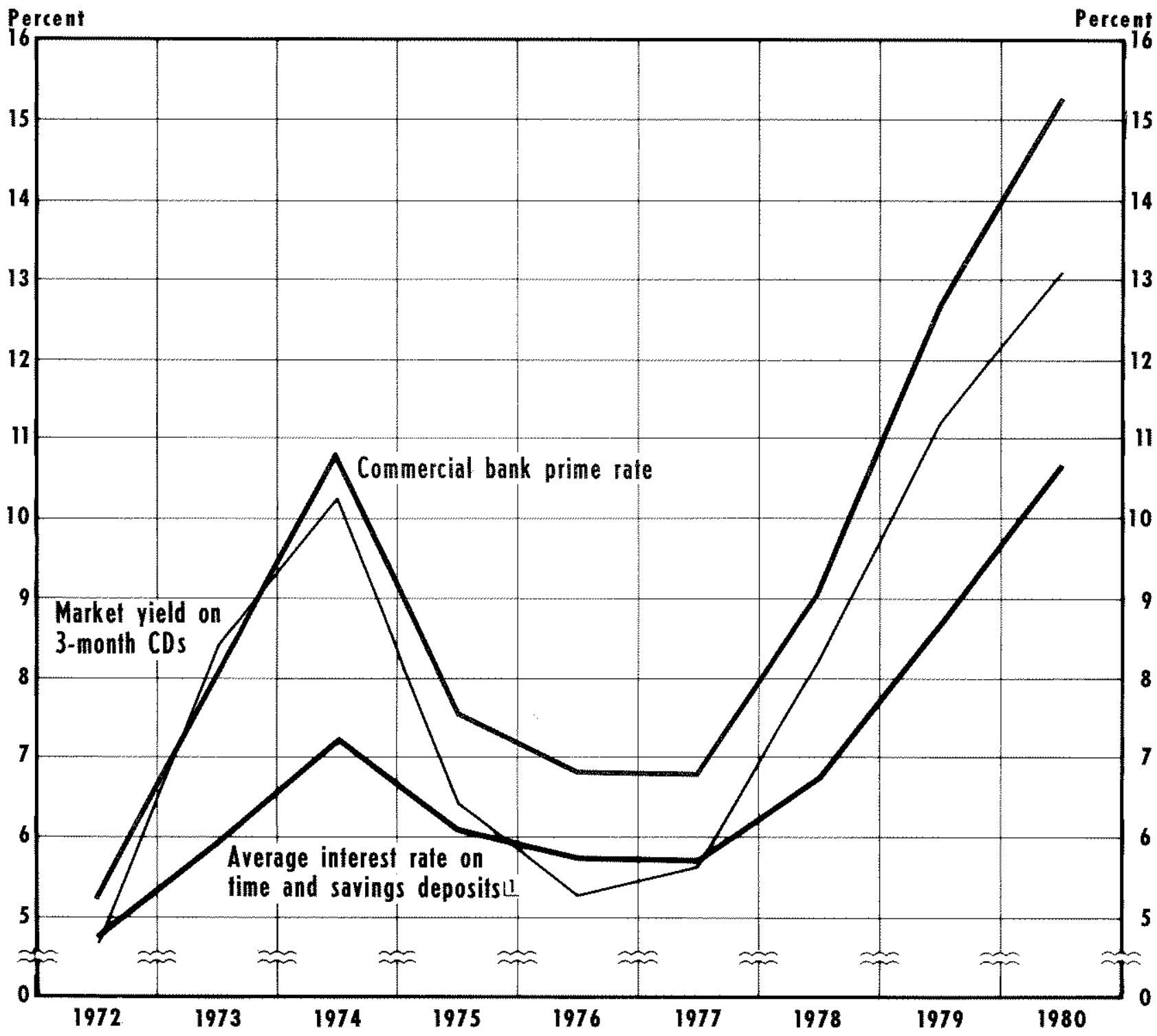

1 At commercial banks

Latest data plotted: 1980

residential mortgage loans made by thrift institutions relative to non-thrift institutions.

Of course, it is possible that the increase in the supply of mortgatge credit by thrifts may not be fully offset by reductions in supply by other lenders.
Again, however, an increase in the net supply of residential mortgage credit would not necessarily depress mortgage interest rates relative to yields on alternative investments. The reason is that predictable adjustments in the demand for credit would 
tend to offset the effects of this shift in the supply on mortgage interest rates. Suppose that, initially, interest rates on residential mortgages are decreased relative to other market interest rates due to an increase in the supply of deposits and mottage loans at thrift institutons. This triggers increases in the quantity of mortgage credit demanded at prevaling motgage interest rates until these rates are, once again, in line with other interest rates. There are a varety of reactions by individuals that would cause an increase in demand for mortgage credit. For example, those seeking to borrow to invest in business finns would take out second mortgages on their homes rather than seek business loans at commercial banks. Also, individuals buying homes would obtain mortgages with smaller percentage downpayments, and invest their wealth instead at interest rates higher than the rates they pay on mortgages.

There is a simple method to test whether the residential mortgage market is truly separate from other credit makets. We can detemine this by examining the correlation between the difference of the average mortgage interest rate and the yield on 10-year Treasury bonds with the mate of growth in time and savings deposits at mutual savings banks and savings and loan associations. If the correlation is significantly negative - if the spread between the mortgage interest rate and the 10 -year bond rate tends to narow when time and savings deposits at thrift institutions grow at a faster rate - the resim dential mortgage market is, to some extent, separated from other credit markets. When their deposits increase ravidy, thrift instutuons reduce the mortgage interest rate relative to other interest rates in order to acquire enough residential mortgages to retain the tax adrantages from specializing in mortgage lending.

In fact, the correlation between the interest rate spread and the growth rate of time and savings deposits at thrift institutions is positive. Using monthly observations from January 1968 through July 1981 , the correlation coefficient is 0.234 , which is statistically significant at the one percent level. Using quarterly averages for $\mathrm{L} / 1968$ through II/1981, the correlation coefficient is 0.262 , which is not statistically significant at the five percent level.

This result confirms the conclusion reached in the previons section. The competitive market theory is consistent with the actual behavion of interest rates.
Therefore, eliminating Regulation $Q$ would not affect mortgage interest rates adversely.

\section{MPLICATIONS FOR INTEREST RATES OF ALL. SAVERS CERTIFICATES}

The analysis presented above has implications for the effects of the All Savers Certificate (ASC) program on interest rates paid by borrowers at depository institutions. ASCs are special time deposits with maturities of one year. The ceiling rate on ASCs is equal to 70 percent of the average yield set in the most recent anction of one-year Treasury securities. ${ }^{13}$ Individuals may declare up to $\$ 1,000$ in interest on ASCs tax free (up to $\$ 2,000$ on joint returns).

Depository institutions issuing ASCs are receiving deposits at interest rates below market rates. For individuals subject to relatively high marginal tax rates, the tax-free yield on ASCs is greater than the after-tax return on many alternative investments.

Depository institutions are required to invest 75 percent of the funds raised by issuing ASCs in housing and agricultural loans. Details of the legislation and the regulations issued to implement the program provide depository institutions with a gleat deal of flexibility in meeting these investment requirements. The objectives for establishing the ASC program, lowever, included increasing the amount of credit avalable to the housing and agricultural sectors of the credit market.

The structure of regulations under the ASC program is similar to that for promoting mortgage lending by thift institations. Diferentals in Reglation $Q$ ceilings have given thrift institutions advantages in attracting deposits, and thrifts have been given tax incentives to specialize in mortgage lending. All depository institutions that take advantage of the ASC program to attract deposits at interest rates below market rates are required to allocate increases in their assets to certain sectors of the credit market.

The analysis developed earlier indicates that the inflow of deposits at institutions given inducements to specialize in montgage lending has not lowered the level of mortgage interest rates relative to other

\footnotetext{
13reatiny secrities with maturities of one year are generally auctioned esery four weks on a Thuska. The average yield on a Thumday auction detemines the new ceiling rate on All Savers Certificates beginning the following Monday.
} 
rates. The $\mathrm{ASC}$ program is therefore unlikely to have any appreciable impact on the interest ates charged on housing and agricultural loans relative to other interest rates. The ASC program may have some effect on the quantity of housing and agricultural loans, as depository institutions and their borrowers develop methods of classifying loans in the catem gories that will meet the investment requirements of the ASC program. The primary effects of the ASC program will be to reduce the interest costs of depository institutions and the income tax of investors.

\section{THE EFFECTS OF ELIMINATING REGULATION Q ON PROFITS OF DEPOSITORY INSTITUTIONS}

Eliminating Regulation $Q$ will raise the interest rates paid to depositors relative to market interest rates. The evidence cited above indicates that borrowers at depository institutions will not pay higher interest rates due to the elimination of Regulation $Q$. Decontrol of interest rates paid on deposits, there fore, will tend to reduce the net income of depository institutions.

Several studies indicate, however, that the net income of depository institutions will not decline by the full amount of the increase in interest paid on deposits. Because interest rate ceilings on deposits have been below market interest rates, depository institutions have increased expendifures to attact deposits by means other than increasing interest payments on deposits. ${ }^{14}$ These non-interest expenm ditures to attract deposits are estimated at between 40 and 50 percent of the direct interest expense depository institutions saved by paying only the ceiling interest rates on deposits rather than market interest rates. ${ }^{15}$

Althougl depository institutions can quickly eliminate some types of non-interest expenditures made to attract deposits, such as gift of merchandise for depositors who open or add to accounts, they will incur losses in eliminating other expenditures. One major expenditure intended to attract deposits has

\footnotetext{
14Thomas Eric Kilcollin and Gerald A. Hanweck, "Regulation Q and Commercial Bank Profitability," Research Papers in Banking and Finatuctal Economics (Board of Governors of the Federal Reserve System, 1981).

"in Taggart, "Effects of Deposit Rate Ceilings," and Lewis I Spellman, "Deposit Ceilings and the Efficiency of Financial Intermediation," Jontral of Finance (March 1980), pp. 129-36.
}

been the opening of branch offices, Since depository institutions have not been allowed to compete directly on the basis of interest rates they offer to pay on deposits, they have been competing indirectly by offering convenient locations for depository services. ${ }^{16}$ Many branches that were profitable when Regulation Q ceilings were below market interest rates will become unprofitable when deposit interest rate cellings are lifted.

\section{CONCLUSIONS}

Under the directives of the Depository Institutions Deregulation Act of 1980, the Depository Institutions Deregulation Committee is in the process of lifting interest rate ceilings on time and savings deposits. That committee has taken some steps to raise the ceilings, but the most significant actions to eliminate the ceilings on deposit interest rates are yet to come.

Some supporters of ceilings on deposit interest rates claim that eliminating the ceilings will cause depository institutions to rase the interest rates they charge borrowers. An analysis of interest rates does not support this view. Interest rates paid by borrowers are determined by market rates that are exempt from Regulation $Q$ ceilings. Consequently, elimination of Regulation $Q$ ceilings will not cause loan rates to rise, but may cause them to decline if depositors save more with higher deposit interest rates. Profits of depository institutions will not decline by the full amount of the increase in interest expense resulting from eliminating Regulation Q, since these institutions will eliminate some noninterest costs that were incurred to attract deposits when Regulation $Q$ ceilings were binding.

Similar implications also hold for the effects of the All Savers Certificate program on interest rates paid by borrowers. Although depository institutions are required to invest at least 75 percent of funds raised by issuing All Savers Certificates in housing and agricultural loans, that requirement is unlikely to result in lower interest rates on such loans relative to other market interest rates.

\footnotetext{
${ }^{16}$ Lawrence J. White, "Price Reglation and Quality Rivalry in at Profit-maximizing Model: The Case of Bank Branching;" fournat of Monew. Credit and Banking (February 1976), pp. 97-106; and Willim M. Peterson, "The Effects of Interest Rate Ceilings on the Number of Banking Offices in the United States," Research Paper No. 8103 (Federal Reserve Bank of New York, 1981 ).
} 